\title{
Use of Hands Up Media to Improve Students' Speaking Ability in English
}

\author{
Ani Agustiyani Maslahah
}

\begin{tabular}{|l|l|l|l|}
\hline Contact: & Ani Agustiyani Maslahah & aniagustiyani10@gmail.com \\
\hline
\end{tabular}

\begin{abstract}
This study involved 30 students consisting of 15 students from the Class X IIS and 15 students from the Class X MIA. Data were collected through observation and documentation. The analysis of the research data was used descriptive quantitative methods with percentages. The percentage results are then consulted with predetermined criteria. The results show the effectiveness of hand puppet props in learning and improving students' abilities. Also, students become more active and motivated by the presence of hand puppet props. Props can increase students' learning motivation, thus supporting a learning atmosphere for students. The evaluation of learning activities is generally good, as seen from the aspects of material suitability, understanding, analysis and synthesis, and learning intensity. This means that students can increase their courage and ability to learn. The evaluation results in cycle 1 increased by $30 \%$, namely from the percentage of pre-cycle completeness $33 \%$ to $63 \%$ in cycle 1 . In comparison, the average student test scores increased from pre-cycle 55.7 to 64.7 in cycle 1. The average understanding of the material presented by the teacher. The results of the evaluation are in a good category, an average of 81.7 in cycle 2 and $90 \%$ of students have complete scores. The results of the observations also showed an increase in student activity from 64.7 in the pre-cycle to 74.83 in the first cycle and the average satisfactory result was 86.4 in the second cycle. This data shows that learning with visual aids can increase students' understanding and courage of the material so that student learning outcomes and activities were increased significantly.
\end{abstract}

KEYWORDS:

Hand Puppet,

Media,

Speaking Ability.

\section{Introduction}

The quality of Human Resources (HR) is a benchmark for the progress of a nation. Education is very necessary for the framework of the formation of HR. Education is the influence of the environment on individuals to produce permanent changes in habits of thought, attitudes, and behavior 
(Thomspson, 1957). Referring to the opinions of these experts, teachers have an interest in the success of education and the development of the potential of students through a learning approach that is in accordance with the curriculum, educational goals, student abilities, learning psychology and resources.

The English curriculum in education at Madrasah Aliyah (MA) emphasizes more on students to learn more actively and flexibly. Learning English emphasizes four aspects, namely aspects of writing, reading, listening, and speaking. For the speaking aspect, the material for the National Examination and Madrasah Examination is not included. So that students think English is said to be successful if they can work on written scores on the English exam. Language is a means of communication, namely through speaking. So far, data from class $X$ students at MA Roudlotusysyubban, odd semester of the 2019/2020 school year, of 30 students, psychomotor scores (skills) in speaking are above the KKM about 11 people. Around 19 people (67\%) have not completed. This data encouraged the writer to think that there needs to be an effort to improve students' speaking skills in English in speaking material using hand puppet media, in even semesters, so that students feel interested and don't feel ashamed to have a dialogue or tell a text or dare to express feelings in English.

Hand puppets (hand puppets) are dolls usually made of cloth/sarong and there is a hole to insert our hands at the bottom. Hand puppet opera can be played by hand puppet players by inserting their hands into the doll. Puppet players can move the doll's head, hands, and body according to what the puppet player wants and wants to convey according to the storyline that will be played. For example, if a player wants to say yes or no, it is enough to move the doll's head down, meaning nodding, and to the right or left, it means rejecting or not. To say a word or voice, the player can change the voice according to the role played. 
In teaching English, especially for the speaking aspect, there are obstacles motivating children for being confident to speak, whether it is just getting acquainted, expressing feelings, or telling experiences. Therefore, it is important to use methods and media that can be interesting and motivating children to speak in English. Teaching English to children and adolescents requires a planned strategy so that they are motivated to enjoy learning by creating things that make them visually interested because one way to get children's attention focused on learning is the use of appropriate teaching aids. This hand puppet can be used in teaching speaking for introduction material, telling names, ages, hobbies, experience, storytelling, and so forth. If children have the courage to play themselves with hand puppets to talk, they will be more developed to engage in dialogue and be able to talk about experiences or stories or fairy tales.

\section{Media and Props}

One of the factors supporting the success of student learning is the existence of teaching aids and learning media that are in accordance with the material to be taught. Learning Media is defined as everything that can be used to channel messages (messages), stimulate the thoughts, feelings, attention and willingness of students so as to encourage the learning process (Sumiati, 2008)

Understanding teaching aids according to Kurt (2012) is a component of learning resources in the student environment that can stimulate students to learn. According to Gagné, Briggs, and Wager (1992), teaching aids are physical vehicles that contain learning materials. According to Halpern and Hakel (2003), macro teaching aids in the entire education system are defined as anything that can stimulate the learning process. It can be concluded that teaching aids are something that can be an intermediary for teachers to make it easier to convey material to students. 
There are several purposes of using teaching aids in teaching speaking in English subjects, including: Clarify information or learning messages, with collaboration through dialogue; Attracting students to arouse interest, activity, and creativity in learning; Make it easier and faster for teachers to present speaking lesson material; Clarify the teaching structure; Motivating students to dare to speak in English.

\section{Methods in Learning English at Madrasah Aliyah}

The learning method used by the teacher allows students to learn the process (learning by process), not just learning the product (learning by product) (Sumiati, 2008). To learn the process does not only involve cognitive values but also includes affective and psychomotor values. Hamzah (2009) in his book, "Learning Model", said that the learning method is defined as the method used by the teacher in carrying out his duties. It is a tool to achieve certain learning goals for the learning method using certain stages. These are the types of methods in learning English as follows.

\section{Assignment Method}

The assignment method is one of the methods used by teachers to teach English by giving assignments that are not time-bound. As an example: The aspect of writing, the teacher assigns students to write texts, self-identity, and others; The aspects of reading, the teacher gives the task of students to read the text observantly and analyze the content of the text; The aspect of listening, the teacher gives students assignments to answer questions from the questions that are heard either directly or using the media. The aspect of Speaking, the teacher gives the task of students to give storytelling, dialogue, and monologue.

\section{Discussion Method}

In learning English, the discussion method is often used because: Democratic in nature; It is an effective way to raise problems; Enhance the 
role of students; Encourages a sense of unity and develops a sense of sociality; Develop leadership.

\section{Lecture Method}

This method is the most frequently used by teachers. In learning with a short time and a lot of material, this lecture method is effectively used. However, if it is not varied with other methods, students will be bored because they seem monotonous, and students are passive. In order for the lecture to be effective, it must be balanced with questions and answers and students are asked to read first before the lecture so that students actively respond to questions according to their knowledge. For learning English, this lecture method is used to explain the content of the material, grammar/grammar and others, especially aspects of reading and writing.

\section{Simulation Method}

Simulation can be interpreted as a way of learning by doing an artificial behavior process (Sumiati, 2008). In learning English, the simulation method is often used for the Speaking aspect, such as using a sociodrama/social drama simulation, psychodrama, or role-playing.

\section{The Use of Hand Puppets for Learning English in Madrasah}

\section{Aliyah}

English education is an important lesson at all levels of education. Based on the objectives listed in the English learning curriculum at the secondary schools or Madrasah Aliyah (MA), it was intended that students have the following abilities; developing communication competence in spoken and written form to reach the level of informational literacy, and having an awareness of the nature and importance of English to improve the nation's competitiveness in a global society that develops students' understanding of the relationship between language and culture. After that, there are many types of learning media, there are positive aspects of using hand puppet 
media or props to teach children to speak fluently, this is based on the results of research that the author has done for some time, which are as follows.

\section{Description}

The implementation of the action began with conducting initial observations carried out, the aim was to find out more deeply the condition of the schools or madrasa, as the class that will receive treatment. These conditions included the physical condition of the class, the condition of students, teachers, the learning process and teaching and learning activities in the classroom as well as educational facilities and infrastructure in the classroom. In the initial observation, the learning activities consist of 3 stages, 1) Initial Activities, 2) Core Activities, and 3) Closing.

In the initial activity in the form of apperception, students are invited to ask questions about the material to be discussed, which ultimately relates to the core material, while the core activities in learning mostly use the lecture method without using any media except English textbooks. The teacher explained more using the lecture method and monotonous dialogue in explaining the concept so that it seems that students only get abstract concepts, do not dare to express feelings and teaching and learning activities are focused on the teacher. In addition, student involvement still seems less than optimal, this can be seen from the passivity and confusion of students in following and answering teacher questions. As for the closing activity, students were given the task of working on questions or evaluations. In the initial reflection through observation, several advantages and disadvantages can be found in learning activities. These advantages include: The learning process has been carried out in a structured and systematic manner following the teaching design, as well as the teaching program; The teacher conveys a lot of information about the concept of material, dialogue using the lecture method in every learning activity. 
While some of the shortcomings in the learning process found are: Learning seems monotonous, one-sided because students are afraid and embarrassed to answer the teacher's questions. This makes students bored. Because it only explains verbally a concept without being assisted by adequate supporting facilities and or media; Students tend to be passive only to answer the teacher's questions without giving any feedback. During this initial observation too, students have not shown the expected behavior. Indeed, students occasionally answered the teacher's questions by rephrasing what the teacher has said, but this was because conventional methods do not provide many opportunities for students to obtain more varied and long-lasting information. After all, they did not emphasize process skills and lack of vocabulary. As a result, students have difficulty understanding the material presented by the teacher.

The advice given was to be able to master the material and provide explanations with teaching aids that attract students' interest so that the learning process runs conducive. From the results of research and observations of student activities and teacher activities, it can be seen the shortcomings as well as the advantages of the learning process. The value of the students' evaluation results in the first cycle got an average score of 64.7 , or the absorption level of mastery of the material was $65 \%$. Of the 30 students there are still 11 students who have scores below the Minimum Completeness Criteria (KKM: 65 ) or $63 \%$ of students still need improvement.

The suggestions given were that the teacher must be able to provide various media, this is by providing various media techniques designed by the teacher, so students would easily remember what has been given in the learning process. In cycle 2, the props used were Hand Puppets which were more varied. Observer and rater 2 observed the learning that takes place. The children are very interested and motivated to follow the lesson by following the steps from the teacher to do storytelling using hand puppets. 
The results of the evaluation scores in the second cycle show an increase in students' understanding of the material, namely the class average value had reached 81.7. The percentage of completeness scores reached $90 \%$. It proved that natural teaching aids have helped their learning process. Students' attention to the teacher's explanation increases, student activity in practice is more evenly distributed, and understanding of terms/language is clearer. But there were still 3 students who have scores below the KKM, namely 3 students who have had a score of 60 .

\section{Reflection}

In the first cycle, the attention of class $X$ students at MA Roudlotusysyubban to the teacher's learning or explanation was still lacking, it was proven that the value of the student evaluation results in the first cycle of the number of students was 30, 11 students scored above 65 (65 = KKM score), and 11 students received the value is below the KKM (Minimum Completeness Criteria), meaning that 11 people must have their scores corrected. As for the average grade, the score is 64.7 , slightly below the KKM.

In the second cycle, the use of hand puppets has aroused enthusiasm for learning and helps teachers in delivering subject matter, so that student learning outcomes also increase. This can be observed from the value of the evaluation results in the second cycle there is an increase. The percentage of students who reached the KKM is $90 \%$. Student activity in cycle I was not maximized, there were still many students who relied on other people in discussion or group work. Only students who became group leaders and students who record the results of active discussions. Moreover, there is one group whose all members actively participate in solving problems, expressing their opinions. All students actively involved in the discussion because they even work in groups but have individual tasks for the results of the discussion. Besides that, the teaching aids brought by students are very supportive of students in learning, so that it 
directly motivated students to learn competitively. Students' understanding of the material began to increase in cycle II. It was proven that they were more active in expressing their opinions, answering questions, or asking and responding to the opinions of other students or other groups.

The results of observations in the pre-cycle of students who got an A score were 2 students, 6 children got $B$ and 10 children got a $C$ score. While children who got a D score were 12 students. This result shows the low motivation and activity of children. In cycle 1 there was a good increase with the value of $C$ being the lowest for 13 children and the others getting $B$ and A. An amazing increase in activity in cycle 2 where children did not get $D$ and $C$ scores. 14 children got $A$ and $B$ scores for 16 children. Students are active in the learning and discussion process, and they are motivated by hand puppet props that the teacher has prepared.

\section{Conclusion}

The learning outcomes in cycle I which were still below the target showed that the learning process was less active, and the teacher had not been able to deliver the material optimally. Besides that, the overall behavioral aspects of learning objectives according to Bloom (1996) which can show a picture of learning outcomes, including cognitive, affective, and psychomotor aspects have not emerged positively, permanently, and thoroughly.

Learning outcomes in cycle II showed progress. The use of hand puppet props has helped students to interact directly, arouse learning motivation, and present messages simultaneously for all students. In classroom management, the teacher has helped students feel the freedom to do what students want (Hall, 1981). An increase in the value of the evaluation results shows that teachers have begun to understand that when teaching for improvement, teachers should start with a reflection by asking themselves, "What do children need? And how to meet the needs of children? (Kohn, 1996). As a result, $80 \%$ of the students felt that the time allocated for 
participating in the lesson was adequate. This shows that the development of English learning by using an environment in the form of hand puppets as a learning resource can create a conducive climate to improve the quality of learning. This result is also supported by a good forum setting so that the atmosphere of the learning room is so pleasant. In the aspect of mastery of materials and methods, the facilitator stated that in terms of the suitability of the educational background to the materials and methods used, all of them stated that they were appropriate. In relation to the suitability aspect of the methods and media used for successful learning according to the indicators of success.

\section{References}

Bloom, R., Mullins, J., \& Paternostro, P. (1996). Changes in Processing Adverbial Conjuncts throughout Adulthood. Applied Psycholinguistics, 17, 105-116.

Gagné, R. M., Briggs, L. J., \& Wager, W. W. (1992). Principles of instructional design (4th ed.). Forth Worth, TX: Harcourt Brace Jovanovich College Publishers.

Hall, J. E. (1981). Max Weber's Methodological Strategy and Comparative Lifeworld Phenomenology. Human Studies, 4(2), 131-143. Retrieved from http://www.jstor.org/stable/20008797

Halpern, D. F., \& Hakel, M. D. (2003). Applying the science of learning to the university and beyond: Teaching for long-term retention and transfer. Change, 35(4), 36-41. Retrieved from https://seaverfaculty.pepperdine.edu/thompson/projects/wasc/Applying the science of learning.pdf

Hamzah, B. U. (2009). Learning Model. Jakarta.

Kohn, A. (1996). Beyond Disipline. Retrieved July 27, 2021, from www.alfiekohn.org

Kurt, S. (2012). Gagne's Nine Events of Instruction. Retrieved January 1, 2021, from https://educationaltechnology.net/gagnes-nine-events-ofinstruction/

Sumiati. (2008). Metode Pembelajaran. Bandung: Wacana Prima.

Thomspson, G. (1957). Website. Retrieved from website Pendidikan.com 